\title{
Energy Drinks: Cardiovascular Complications
}

\author{
Higgins J $P^{*}$ and J ogimahanti AV \\ McGovern Medical School, The University of Texas \\ Health Science Center at Houston (UTHealth) Houston, \\ TX, USA \\ *Corresponding author: J ohn P Higgins, Professor \\ of Medicine, The Division of Cardiovascular Diseases, \\ Cardiology Department, Lyndon B. J ohnson General \\ Hospital, McGovern Medical School at The University \\ of Texas Health Science Center at Houston (UTHealth), \\ 6431 Fannin St., MSB 1.248, Houston, TX 77030, USA
}

Received: October 29, 2021; Accepted: November 25, 2021; Published: December 02, 2021

\section{Introduction}

Energy Drinks (EDs) are caffeinated beverages that are marketed to improve energy, athletic performance, concentration, endurance, and weight loss [1-4]. The consumption of EDs has increased significantly in recent years, with a growing market that is estimated to reach $\$ 61$ billion by 2021 worldwide.

It is important to recognize the difference between EDs and traditional soft drinks such as sodas, as well as coffee, tea, sports drinks (such as Gatorade), juices, or flavored water [5]. Some believe that "Energy drinks are the Wild West of the soft drinks industry: often shockingly and unnecessarily high in sugar and caffeine..." [6].

EDs typically contain taurine (an amino acid), niacin, pyridoxine, cyanocobalamin (B12), riboflavin (B2), ginseng extract, glucuronolactone (a glucose metabolite), inositol (B8), guarana (contains caffeine, theobromine, and theophylline), ephedra, yohimbine, Ginkgo biloba, kola nut, theophylline, sugars, vitamins, herbs, and L-carnitine [7]. Caffeine has even been added to foods too, and examples of foods and beverages caffeine content are freely available $[8,9]$.

A typical ED contains $0.34 \mathrm{mg}$ of caffeine per $\mathrm{mL}$, which exceeds the FDA imposes a limit of $71 \mathrm{mg}$ of caffeine per $12 \mathrm{fl} \mathrm{oz} \mathrm{of} \mathrm{soda} \mathrm{(200}$ parts per million) or $0.2 \mathrm{mg}$ of caffeine per $\mathrm{mL}[2,8,9]$. Some EDs do not disclose total caffeine, as they may fail to account for the caffeine, contributed by "energy blend" ingredients (guarana, kola nut, yerba mate) $[10,11]$.

While most healthy adults can safely consume up to $400 \mathrm{mg}$ per day, other groups should be cautious $[8,12]$. Pregnant women should limit ED use to 200mg per day, while adolescent adolescents and children should completely avoid consumption due to unknown risk profiles [13-16]. Despite the risk, consumption of EDs is highest among adolescents/young students and declines with increasing age [13]. EDs are now consumed by $30 \%-50 \%$ of adolescents, with $31 \%$ of 12 -19-year-olds reporting regular use [2,15]. Up to $78 \%$ of young adults and students are consuming EDs on a weekly basis $[17,18]$.

In a recent metaanalysis, adverse effects of EDs were common. Frequently reported adverse events in the pediatric population were insomnia (35\%), stress (35\%), and depressive mood (23\%). Frequently reported adverse events in the adult population were insomnia (25\%), jitteriness/restlessness/shaking hands (30\%), and gastrointestinal upset (22\%).

ED consumption has been significantly associated with lower breakfast frequency, higher sugar-sweetened soda intake, video game use, unhealthy dietary and weight-control behaviors, insomnia, and later substance use $[17,19,20]$. ED consumption is associated with adolescent use of alcohol, tobacco, cannabis, prescription stimulants, and analgesics.

Alcoholic beverages prepared with EDs are popular amongst adolescents and college students and associated with smoking and illicit drug use [21,22-24]. Harmful consequences include automobile fatalities and increased rates of sexual abuse. [25,26]. Moreover, alcohol consumption can increase the half-life of caffeine by up to $72 \%$, which may potentiate the ED exposure effects [27]. Combining energy drinks with alcohol also precipitates adverse cardiovascular events, posing a risk to the health of children and adolescents.

Emergency department visits related to complications of ED consumption are increasing in frequency, whether for toxicity or simply exposure-related, including young children [28-30]. Consumption of EDs has been associated with exacerbation of underlying medical conditions too [2,30-34].

Cardiovascular complications associated with EDs include increased cardiometabolic risk with high intake of sugar, short-term blood pressure increases and a decrease in cerebral blood flow due to the caffeine content, increased or decreased blood pressure from taurine, unmasked cardiac conditions, such as channelopathies, and atrial and ventral arrhythmias. Cardiovascular complications can also arise when EDs are mixed with stimulants, amiodarone, potent CYP1A2 inhibitors, warfarin, digoxin, or corticosteroids. Adverse events associated with energy drinks may have a genetic predisposition.

This review will focus on ED complications involving the cardiovascular system. 
Table 1: Cardiovascular complications associated with energy drinks (EDs).

\section{Acute Effects}

Increased Blood Pressure (Table 2)

Increased Heart Rate (Table 3)

Increased Corrected QT (QTc) Interval (Table 4)

Supraventricular Arrythmia (Table 5)

Ventricular Arrythmia (Table 6)

Coronary Artery Spasm (Table 7)

Coronary Artery Thrombosis (Table 8)

Spontaneous Coronary Artery Dissection (Table 9)

Acute Coronary Syndrome (Table 10)

Stress-Induced (Takotsubo) Cardiomyopathy

Aortic Dissection (Table 11)

Postural Orthostatic Tachycardia Syndrome (POTS)

Sudden Cardiac Death (Table 12)

Endothelial Dysfunction (Table 13)

\begin{tabular}{|l|}
\hline \multicolumn{1}{|c|}{ Possible Chronic Effects } \\
\hline Hypertension \\
\hline Obesity \\
\hline Coronary Artery Disease \\
\hline Atherosclerosis \\
\hline Cerebrovascular Disease \\
\hline Peripheral Arterial Disease \\
\hline
\end{tabular}

\section{Cardiovascular Complications}

Cardiovascular complications of consuming EDs may be related to acute or chronic exposure. These are listed in Table 1 and are detailed below.

\section{Acute Effects}

\section{Increased blood pressure}

Numerous studies have associated EDs and their ingredients with acute hypertension (Table 2) $[35,36]$. Acute caffeine consumption can increase blood pressure and heart rate by increasing plasma renin, catecholamines, and dopamine [11,37]. In addition, synergistic effects between components of the "energy blend" used in EDs may also contribute, especially in children and hypertensive patients $[1,35]$. The effects of caffeine on hemodynamics can last up to $5 \mathrm{~h}$ after ED ingestion. Such effects may be amplified by performing physical activity just after consumption [38-40].

Recap: A typical increase in systolic and diastolic blood pressure in normal healthy persons 1-2 $\mathrm{h}$ following consumption of ED is approximately 4-9 $\mathrm{mmHg}$ and 1-6 $\mathrm{mmHg}$ respectively.

\section{Increased heart rate}

Acute consumption of EDs has been associated with small but significant increases in heart rate (Table 3 ).

Recap: A typical increase in heart rate in normal healthy persons 1-2 $\mathrm{h}$ following consumption of ED is approximately 2-8 beats per minute.

\section{Increased corrected QT (QTc) interval}

Possibly, due to the effect of ingredients such as taurine on multiple cardiac ion channels $[49,50]$, EDs have been associated with prolongation of the QT interval, although not all studies showed a significant increase (Table 4) [51,54].

Recap: A typical increase in heart rate in normal healthy persons 1-2 $\mathrm{h}$ following consumption of ED is approximately 4-8 milliseconds.

\section{Supraventricular arrhythmia}

Consumption of EDs and other energy products has been associated with precipitation and/or exacerbation of supraventricular arrhythmia (Table 5) [15,55]. Atrial fibrillation, which is rare in the pediatric population, has been observed following acute ingestion of EDs in young adults [56,57].

Recap: Supraventricular arrhythmias, especially atrial fibrillation, can be seen in normal healthy persons following consumption of EDs.

\section{Ventricular arrhythmia}

Sudden cardiac death due to ventricular arrythmias has been associated with ED use through means such as increasing catecholamines, electrolyte abnormalities inducing hypokalemia, or inactivation of sodium channels (Table 6) [10]. In addition, high doses of caffeine, like those found in EDs, may exacerbate cardiac conditions such as ion channelopathies and hypertrophic cardiomyopathy [2]. Taurine and guarana also have proarrhythmic properties, making their consumption by patients with underlying structural heart disease potentially dangerous [63].

Recap: Ventricular arrhythmias (ventricular tachycardia and ventricular fibrillation) can be seen in normal healthy persons or in those with underlying cardiovascular conditions such as Brugada Syndrome, usually following consumption of multiple EDs over a short period of time.

\section{Coronary artery spasm}

Consuming multiple cans of energy drinks with resultant high levels of caffeine (400-800 mg) as well as taurine (2000-8000 mg) have been associated with coronary artery vasospasm (Table 7$)$. The mechanism is likely secondary to inhibition of adenosine A2 channels by caffeine [70,71]. However, taurine modulates calcium signaling and high levels can affect calcium concentration both intra- and extracellularly [11]. In addition, there is some evidence that taurine may enhance the physiologic actions of caffeine, leading to increased inotropy, and thus may contribute to coronary artery spasm [70,72].

Recap: Coronary artery spasm may occur in normal healthy persons following consumption of multiple (2-8 cans) of EDs containing high levels of caffeine and taurine.

\section{Coronary artery thrombosis}

Coronary artery thrombosis has been associated with consumption of multiple ( $\geq 3$ cans) EDs and sometimes in combination with alcohol (Table 8) [74,75].

Recap: Coronary artery thrombosis may occur in normal healthy persons following consumption of multiple (3 or more cans) of EDs.

\section{Spontaneous coronary artery dissection}

Spontaneous coronary artery dissection has been described in 
Table 2: Increased blood pressure associated with energy drinks.

\begin{tabular}{|c|c|c|c|}
\hline Authors (Ref) & Population & Energy Drink (ED) & Results \\
\hline $\begin{array}{l}\text { Grasser et al. } \\
\text { [35] }\end{array}$ & 12 women & $355 \mathrm{~mL}$ of Red Bull & $\begin{array}{l}\text { SBP*: Increased by } 5.2^{\text {DBP*: Increased by } 6.1}\end{array}$ \\
\hline Steinke et al. [41] & 15 healthy $18-40$ year olds & Two cans of $500 \mathrm{~mL}$ EDs & $\begin{array}{l}\text { SBP: Increased by } 7.2 \% \text { and } \\
9.6 \% \\
\text { DBP: Increased by } 7.0 \% \text { and } \\
7.8 \%\end{array}$ \\
\hline Franks et al. [42] & 9 Subjects (5 females, mean age: 27.7 ) & Red Bull & $\begin{array}{l}\text { SBP: Increased by } 5.8 \mathrm{mmHg} \\
\text { DBP: Increased by } 5.4 \mathrm{mmHg}\end{array}$ \\
\hline Elitok et al. [36] & 50 young, healthy subjects & Red Bull & $\begin{array}{l}\text { SBP: Increased by } 9 \mathrm{mmHg} \\
\text { DBP: Increased by } 3 \mathrm{mmHg}\end{array}$ \\
\hline Peveler et al. [43] & 15 recreationally active men and women & $\begin{array}{ll}- & \text { Red Bull } \\
- & \text { Monster } \\
- & 5 \text { hour Energy }\end{array}$ & $\begin{array}{l}\text { SBP: } \\
\text { Increased by } 6.94 \mathrm{mmHg} \\
\text { Increased by } 9.54 \mathrm{mmHg} \\
\text { Increased by } 8.07 \mathrm{mmHg} \\
\text { DBP: } \\
\text { Increased by } 0.67 \mathrm{mmHg} \\
\text { Increased by } 1.33 \mathrm{mmHg} \\
\text { Increased by } 1.33 \mathrm{mmHg}\end{array}$ \\
\hline Kozik et al. [44] & $\begin{array}{l}14 \text { healthy young subjects (mean age } 28.6 \text { ) } \\
38 \text { adults ( } 19 \text { women, mean BMI } 32 \mathrm{~kg} / \mathrm{m}^{2} \text {, mean age } 22 \mathrm{y} \text { ) }\end{array}$ & $\begin{array}{l}32 \text { ounces of Monster energy } \\
\text { drink }\end{array}$ & SBP: Increased by $18 \mathrm{mmHg}$ \\
\hline Basari et al. [45] & 38 adults (19 women, mean BMI 32 kg/m², mean age 22y) & 3-4 cans of $250 \mathrm{~mL}$ Red Bull & SBP: Increased by $3.8 \mathrm{mmHg}$ \\
\hline Nowak et al. [46] & Young adults (average age 25years; 49 female and 39 male participants) & $600 \mathrm{~mL}$ of an unspecified ED & $\begin{array}{l}\text { SBP: Increased by } 5.6 \mathrm{mmHg} \\
\text { DBP: Increased by } 10.9 \mathrm{mmHg}\end{array}$ \\
\hline $\begin{array}{l}\text { Brothers et al. } \\
{[47]}\end{array}$ & 15 participants & $\begin{array}{ll}- & 16 \text { oz Monster Ed } \\
- & 24 \text { oz of Monster ED } \\
- & \text { Coffee }\end{array}$ & $\begin{array}{l}\text { SBP: } \\
\text { Decreased by } 2 \mathrm{mmHg} \\
\text { Decreased by } 2 \mathrm{mmHg} \\
\text { No change in } \mathrm{mmHg} \\
\text { DBP: } \\
\text { No change in } \mathrm{mmHg} \\
\text { No change in } \mathrm{mmHg} \\
\text { Increase in } 1 \mathrm{mmHg}\end{array}$ \\
\hline Gray et al. [48] & 24 LQTS patients aged $16-50$ years & 2 Red bull sugar-free cans & $\begin{array}{l}\text { SBP: Increased by } 6 \mathrm{mmHg} \\
\text { DBP: Increased by } 6 \mathrm{mmHg}\end{array}$ \\
\hline Shah et al. [49] & $\begin{array}{l}\text { Healthy volunteers between } 18 \text { and } 40 \text { years of age with no premorbid } \\
\text { conditions were included }\end{array}$ & $\begin{array}{l}1 \text { bottle }(2 \mathrm{fl} . \mathrm{Oz}) \text { of } 5 \text {-hour } \\
\text { Energy }\end{array}$ & $\begin{array}{l}\text { SBP: Increased by } 5 \mathrm{mmHg} \\
\text { DBP: Increased by } 4 \mathrm{mmHg}\end{array}$ \\
\hline
\end{tabular}

Table 3: Increased heart rate associated with energy drinks.

\begin{tabular}{|c|c|c|c|}
\hline Authors (Ref) & Population & Energy Drink (ED) & Results \\
\hline $\begin{array}{l}\text { Grasser et al. } \\
\text { [35] }\end{array}$ & 25 young non-obese and healthy subjects & Red Bull & $\begin{array}{l}\text { Increase in } \mathrm{HR}^{\star} \text { relative to water } \\
\text { control }\end{array}$ \\
\hline $\begin{array}{l}\text { Steinke et al. } \\
{[41]}\end{array}$ & 15 healthy $18-40$-year-olds & 2-4 hours after ED consumption & $\begin{array}{l}\text { Increase in HR by } 7.8 \% \text { and } \\
11.0 \%\end{array}$ \\
\hline Elitok et al. [36] & 50 young, healthy subjects (mean age 25 -year-old) & Red Bull & Increase in HR by 8 bpm \\
\hline Nowak et al. [46] & $\begin{array}{l}\text { Young adults (average age 25years; } 49 \text { female and } 39 \text { male participants) in } \\
\text { Bydgoszcz, Poland }\end{array}$ & $600 \mathrm{~mL}$ of an unspecified ED & Increase in HR by $3.8 \mathrm{bpm}$ \\
\hline
\end{tabular}

*HR: Heart Rate

association with ED consumption in a 13-year-old and 25-year-old male, with likely excess consumption [76,77] (Table 9).

Recap: Spontaneous coronary artery dissection may occur in normal healthy persons following consumption of multiple (3 or more cans) of EDs.

\section{Acute coronary syndrome}

Acute coronary syndrome in association with energy drink consumption has been described in young males, age 17-32 years old, with multiple cans of EDs typically being consumed $[66,69,73,75,76,78]$. Some required stenting, others were found to have thrombosis or spasm. The etiology may include high cardiovascular demand from excess caffeine, coronary vasospasm, endothelial dysfunction, and a temporary hypercoagulable state.
A notable example is was a 26-year-old Hispanic male with a 2-year history of smoking presented with an acute ST-Elevation Myocardial Infarction (Table 10) [76]. The patient reported consuming between eight and ten $473 \mathrm{~mL}$ cans of ED per day (Monster, Rockstar, and others). Cardiac catheterization subsequently confirmed total occlusion of his left circumflex coronary artery; the patient received a drug-eluting stent with resolution of his electrocardiogram changes.

Recap: Acute coronary syndrome may occur in normal healthy persons following consumption of multiple (usually 3-5 or more cans) of EDs.

\section{Stress-induced (Takotsubo) cardiomyopathy}

EDs contain sympathomimetic substances such as caffeine and others. Caffeine is a competitive antagonist of adenosine receptors 
Table 4: Increased Corrected QT (QTC) Interval associated with energy drinks.

\begin{tabular}{|c|c|c|c|}
\hline Authors (Ref) & Population & Energy Drink (ED) & Results \\
\hline Steinke et al. [41] & 15 healthy $18-40$ year olds & 2-4 hours after ED consumption & $\begin{array}{l}\text { Increase in QTc by } 2.4 \% \text { and } \\
5.0 \%\end{array}$ \\
\hline $\begin{array}{l}\text { Rottlaender D. } \\
{[52]}\end{array}$ & 22 year old female with out of hospital cardiac arrest & $\begin{array}{l}\text { Consumed six cans of caffeinated ED } \\
\text { within } 4 \text { hours }\end{array}$ & $\begin{array}{l}\text { Increased to } 526 \mathrm{~ms}^{*} \text { from } \\
\text { baseline } 419\end{array}$ \\
\hline $\begin{array}{l}\text { Dufendach et } \\
\text { al. [53] }\end{array}$ & 13-year-old-girl with Type I Long QT Syndrome (LQTS) & Consumed one $16 \mathrm{oz}$. can of an ED & Increased to $561 \mathrm{~ms}$ \\
\hline $\begin{array}{l}\text { Brothers et al. } \\
{[47]}\end{array}$ & 15 healthy participants & $\begin{array}{ll}- & 16 \mathrm{oz} \text { Monster } \\
- & 24 \mathrm{oz} \text { Monster } \\
- & \text { Coffee }\end{array}$ & $\begin{array}{ll}- & \text { Increased by } 6 \mathrm{~ms} \\
\text { - } & \text { Increased by } 8 \mathrm{~ms} \\
\text { - } & \text { Increased by } 4 \mathrm{~ms} \\
\end{array}$ \\
\hline Basari et al. [45] & 38 adults (19 women, mean BMI $32 \mathrm{~kg} / \mathrm{m}^{2}$, mean age $22 \mathrm{y}$ ) & 3-4 cans of $250 \mathrm{~mL}$ Red Bull & Increased by $7.5 \mathrm{~ms}$ \\
\hline Gray et al. [48] & 24 LQTS patients aged $16-50$ years & Unspecified ED & Increased by $4 \mathrm{~ms}$ \\
\hline Shah et al. [49] & $\begin{array}{l}\text { Healthy volunteers between } 18 \text { and } 40 \text { years of age with no premorbid } \\
\text { conditions were included }\end{array}$ & 1 bottle (2 fl. Oz) of 5-hour Energy & Decreased by $2 \mathrm{~ms}$ \\
\hline
\end{tabular}

*ms: milliseconds.

Table 5: Supraventricular Arrythmia associated with energy drinks.

\begin{tabular}{|c|c|c|c|}
\hline $\begin{array}{c}\text { Authors } \\
\text { (Ref) }\end{array}$ & Population & Energy Drink (ED) & Results \\
\hline $\begin{array}{l}\text { Izquierdo } \\
\text { et al. [58] }\end{array}$ & 13-year-old healthy boy in Spain & Unspecified "Eds" & $\begin{array}{l}\text { Atrial fibrillation with rapid ventricular } \\
\text { response }\end{array}$ \\
\hline $\begin{array}{l}\text { Nagajothi } \\
\text { et al. [59] }\end{array}$ & 23-year-old woman with no medical history & $\begin{array}{l}\text { GNC Speed Shot (GNC Corporation, Pittsburgh, PA, USA) } \\
\text { and a Mountain Dew (PepsiCo, Inc., Purchase, NY, USA) } \\
\text { soda drink }\end{array}$ & $\begin{array}{l}\text { Narrow Complex Tachycardia with } \\
\text { Ventricular Rate of } 219\end{array}$ \\
\hline $\begin{array}{l}\text { Kaoukis et } \\
\text { al. [60] }\end{array}$ & 24-year-old man & Unspecified ED & $\begin{array}{l}\text { Supraventricular and Ventricular } \\
\text { Tachycardia, Later Diagnosed as Takotsubo } \\
\text { Cardiomyopathy }\end{array}$ \\
\hline $\begin{array}{l}\text { Peake et } \\
\text { al. [61] }\end{array}$ & 58-year-old previously healthy male & $\begin{array}{l}\text { One bottle }(1000 \mathrm{~mL}) \text { per week of a highly caffeinated } \\
\text { (caffeine content } 4.04 \mathrm{mg} / \mathrm{mL} \text { ) commercially available ED for } \\
\text { six months }\end{array}$ & $\begin{array}{l}\text { Atrial fibrillation with rapid ventricular } \\
\text { response }\end{array}$ \\
\hline $\begin{array}{l}\text { Di Rocco } \\
\text { et al. [57] }\end{array}$ & $\begin{array}{l}\text { Two Caucasian Adolescent Boys, aged } 14 \\
\text { and } 16, \text { with no significant past medical } \\
\text { history }\end{array}$ & One Can of Red Bull & Atrial Fibrillation \\
\hline $\begin{array}{l}\text { Mattioli et } \\
\text { al. [62] }\end{array}$ & $\begin{array}{l}\text { 22-year-old man, with a negative family, } \\
\text { personal, and pharmacological history }\end{array}$ & $750 \mathrm{~mL}$ of ED & $\begin{array}{l}\text { Atrial fibrillation with rapid ventricular } \\
\text { response }\end{array}$ \\
\hline $\begin{array}{l}\text { Mattioli et } \\
\text { al. [62] }\end{array}$ & $\begin{array}{l}\text { 23-year-old-man, without previous cardiac } \\
\text { disease or pharmacological treatment }\end{array}$ & $600 \mathrm{~mL}$ of ED & $\begin{array}{l}\text { Atrial fibrillation with rapid ventricular } \\
\text { response }\end{array}$ \\
\hline
\end{tabular}

Table 6: Ventricular Arrythmia associated with energy drinks.

\begin{tabular}{|l|l|l|l|}
\hline \multicolumn{1}{|c|}{ Authors (Ref) } & \multicolumn{1}{|c|}{ Population } & \multicolumn{1}{|c|}{ Energy Drink (ED) } \\
\hline Avci et al. [64] & 28-year-old-man & Three cans of an ED \\
\hline Cannon et al. [65] & 25-year-old woman with pre-existing mitral valve prolapse & $\begin{array}{l}\text { 55mL of Race 2005 Energy Blast with } \\
\text { Guarana and Ginseng }\end{array}$ & Ventricular Tachycardia \\
\hline Berger et al. [66] & 28-year-old healthy man & $7-8$ cans of unspecified EDs \\
\hline $\begin{array}{l}\text { Rutledge et al. } \\
\text { [67] }\end{array}$ & 24-year-old male with no previous medical history & Redbull ED & Intractable Ventricular Fibrillation \\
\hline $\begin{array}{l}\text { Goldfarb et al. } \\
\text { [68] }\end{array}$ & 19-year-old man & Monster ED & Ventricular Fibrillation \\
\hline $\begin{array}{l}\text { Goldfarb et al. } \\
\text { [68] }\end{array}$ & 57-year-old male & Multiple NOS ED & Ventricular Fibrillation \\
\hline Kaoukis et al. [60] & 24-year-old & Unspecified ED & Cardiac Arrest \\
\hline $\begin{array}{l}\text { Ward et al. [63] } \\
\text { 45-year-old man with a history of tetralogy of Fallot repair at age }\end{array}$ & 3 Red Bull EDs & $\begin{array}{l}\text { Supraventricular and Ventricular } \\
\text { Tachycardia }\end{array}$ \\
\hline $\begin{array}{l}\text { Hanan Israelit et } \\
\text { al. [69] }\end{array}$ & 24-year-old Caucasian man with a history of mild hypertension & 20 cans of ED “XL" \\
\hline
\end{tabular}

$\mathrm{A} 1$ and $\mathrm{A} 2 \mathrm{~A}$ in the central nervous system and myocardium, altering neurotransmitter release and increasing heart rate respectively [8]. Caffeine also induces catecholamine release and causes a rise in intracellular calcium within myocytes, especially when consumed in massive amounts $[8,72,79]$

Such catecholamine surges can precipitate Stress-Induced (Takotsubo) Cardiomyopathy: A 24-year-old man presented with palpitations, chest pain, and acute respiratory failure shortly after ingesting an ED [60]. Frequent runs of supraventricular and ventricular tachycardia were noted. His electrocardiogram showed sinus tachycardia and nonspecific T-wave inversion in leads I and aVL; echocardiogram, showed a reduced left ventricular ejection fraction of $35 \%$, and a diagnosis of Stress-Induced (Takotsubo) Cardiomyopathy was made.

Recap: Stress-Induced (Takotsubo) Cardiomyopathy rarely can be seen in normal healthy persons following consumption of EDs. 
Table 7: Coronary Artery Spasm associated with energy drinks.

\begin{tabular}{|l|l|l|l|}
\hline \multicolumn{1}{|c|}{ Authors (Ref) } & \multicolumn{1}{c|}{ Population } & \multicolumn{1}{c|}{ Energy Drink (ED) } & Results \\
\hline Scott et al. [70] & 19-year-old-man & 2-3 Red Bull ED weekly & Coronary Artery Vasospasm \\
\hline Berger et al. [66] & 28-year-old healthy man & $7-8$ cans of an unspecified ED & Coronary Artery Vasospasm \\
\hline Wilson et al. [73] & 17-year-old male & 3-4 Red Bull with 2-3 Monster & Coronary Artery Vasospasm \\
\hline
\end{tabular}

Table 8: Coronary Artery Thrombosis associated with energy drinks.

\begin{tabular}{|l|l|l|l|l|}
\hline $\begin{array}{c}\text { Authors } \\
\text { (Ref) }\end{array}$ & \multicolumn{1}{|c|}{ Population } & \multicolumn{1}{c|}{ Energy Drink (ED) } & \multicolumn{1}{c|}{ Symptoms } & \multicolumn{1}{c|}{ Results } \\
\hline $\begin{array}{l}\text { Benjo et al. } \\
\text { [74] }\end{array}$ & $\begin{array}{l}\text { 24-year-old African- } \\
\text { American male }\end{array}$ & $\begin{array}{l}\text { Three drinks of vodka } \\
\text { mixed with an ED }\end{array}$ & $\begin{array}{l}\text { Nausea, Emesis, Palpitations, Severe } \\
\text { Retrosternal Chest Pain }\end{array}$ & Myocardial Infarction with Topnonin I of 38ng/mL \\
\hline $\begin{array}{l}\text { Unal et al. } \\
\text { [75] }\end{array}$ & $\begin{array}{l}\text { 32-year-old previously } \\
\text { healthy man }\end{array}$ & $\begin{array}{l}\text { Five bottles of energy } \\
\text { drink }\end{array}$ & $\begin{array}{l}\text { Retrosternal chest pain, palpations, and } \\
\text { emesis }\end{array}$ & $\begin{array}{l}\text { Angiography demonstrated large thrombus occupying } \\
\text { nearly 90\% of L Main Coronary Artery }\end{array}$ \\
\hline
\end{tabular}

Table 9: Spontaneous Coronary Artery Dissection associated with energy drinks.

\begin{tabular}{|c|c|c|c|c|}
\hline Authors (Ref) & Population & Energy Drink (ED) & Symptoms & Results \\
\hline $\begin{array}{l}\text { Solomin et al. } \\
{[76]}\end{array}$ & 13-year-old male & $\begin{array}{l}\text { Ingested an unknown } \\
\text { ED }\end{array}$ & $\begin{array}{l}\text { Acute-onset, "crushing", } \\
\text { mid-sterna chest pain }\end{array}$ & $\begin{array}{l}\text { ECG revealed sinus rhythm 2- to 3-mm ST-segment elevations in leads } \\
\text { II, III, aVF, and V3 through V5 }\end{array}$ \\
\hline $\begin{array}{l}\text { Zacher et al. } \\
{[77]}\end{array}$ & 25-year-old male & $\begin{array}{l}\text { Consumed "more than } 8 \\
\text { cans" of EDs }\end{array}$ & $\begin{array}{l}\text { Chest Pain, persistent } \\
\text { vomiting }\end{array}$ & $\begin{array}{l}\text { ECG showed a sinus rhythm with ST-segment elevation in I, aVL, and } \\
\text { V II, III, aVF, and V3 through V1-V4 and corresponding inferior ST- } \\
\text { segment-depression }\end{array}$ \\
\hline
\end{tabular}

Table 10: Acute Coronary Syndrome associated with energy drinks.

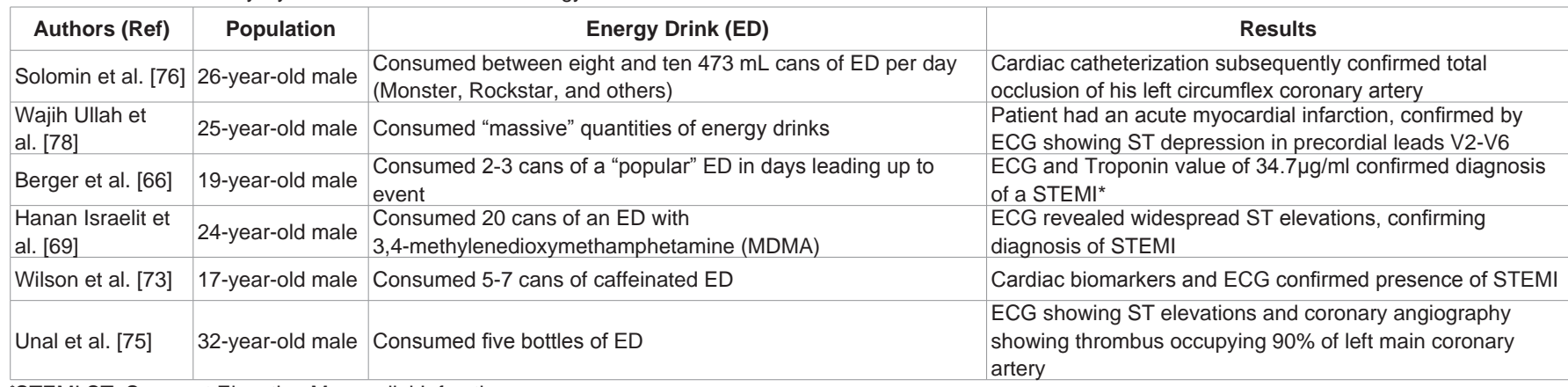

*STEMI ST: Segment Elevation Myocardial Infarction.

Table 11: Aortic Dissection associated with energy drinks.

\begin{tabular}{|l|l|l|l|}
\hline \multicolumn{1}{|c|}{ Authors (Ref) } & \multicolumn{1}{|c|}{ Population } & \multicolumn{1}{|c|}{ Energy Drink (ED) } & \multicolumn{1}{|c|}{ Results } \\
\hline Jonjev et al. [81] & 54-year-old Caucasian man with uncontrolled hypertension and obesity & 4-5 Unspecified EDs & $\begin{array}{l}\text { Acute Aortic Dissection (De Bakey } \\
\text { Type I) }\end{array}$ \\
\hline Jonjev et al. [81] & 26-year-old Caucasian man with history of bicuspid aortic valve & 5-6 Unspecified EDs & Aortic Dissection (De Bakey Type II) \\
\hline Jonjev et al. [81] & $\begin{array}{l}\text { 48-year-old Caucasian man with history of hypertension and myocardial } \\
\text { infarction }\end{array}$ & "Several" High Energy Drinks & Aortic Dissection (De Bakey Type I) \\
\hline
\end{tabular}

Table 12: Sudden Cardiac Death associated with energy drinks.

Table 12: Sudden Cardiac Death associated with energy drinks.
\begin{tabular}{|l|l|l|l|}
\hline \multicolumn{1}{|c|}{ Authors (Ref) } & \multicolumn{1}{|c|}{ Population } & \multicolumn{1}{|c|}{ Energy Drink (ED) } & \multicolumn{1}{|c|}{ Results } \\
\hline CFSAN Adverse Event Reporting System [92] & 14-year-old girl & 48 oz of Monster ED & Cardiac Arrythmia \\
\hline CFSAN Adverse Event Reporting System [93] & 18 -year-old man & 2 cans of Red Bull ED & Sudden Death During Basketball \\
\hline CFSAN Adverse Event Reporting System [94] & 16 -year-old girl & "Several" Red Bull Eds & Cardiac Arrest \\
\hline
\end{tabular}

\section{Aortic dissection}

The sympathetic surge and associated acute increase in blood pressure and heart rate associated with ED consumption described above is associated with precipitation of aortic dissection in those with an underlying predisposition (Table 11) $[1,80]$. It is important to note that patients with underlying cardiovascular diseases are more likely to have acute aortic dissection, especially during conditions of changes in cardiovascular hemodynamics or increased shear stress [82]. Several of the cases described had a clear predisposition, yet one did not. Importantly, in all of these cases, the ruptures were preceded by the consumption of significant amounts of EDs (roughly 400mg of caffeine and $5000 \mathrm{mg}$ of taurine), thereby suggesting that the aortic dissection may have been caused by the acute elevations in heart rate, blood pressure, and cardiac contractility from ED use.

Recap: Aortic dissection (DeBakey I and II) can be precipitated in those with or without known risk factors for aortic dissection (e.g., presence of a dilated ascending aorta) following binge consumption of EDs.

\section{Postural orthostatic tachycardia syndrome (POTS)}

Taurine and caffeine are the ingredients of EDs that can directly or indirectly significantly affect cardiovascular function 
Table 13: Endothelial Dysfunction associated with energy drinks.

\begin{tabular}{|c|c|c|c|}
\hline Authors (Ref) & Population & $\begin{array}{l}\text { Energy Drink } \\
\quad \text { (ED) }\end{array}$ & Results \\
\hline $\begin{array}{l}\text { Worthley et al. } \\
\text { [90] }\end{array}$ & 50 healthy young adults & $\begin{array}{l}250 \mathrm{~mL} \text { of a } \\
\text { sugar-free ED }\end{array}$ & An acute increase in platelet aggregation and decreased endothelial function. \\
\hline $\begin{array}{l}\text { Higgins et al. } \\
\text { [89] }\end{array}$ & $\begin{array}{l}11 \text { healthy medical students ( } 9 \text { males, } \\
\text { average age } 24.5 \text { years, average BMI } \\
\left.22.8 \mathrm{~kg} / \mathrm{m}^{2}\right) \text {. }\end{array}$ & $\begin{array}{l}\text { 24-oz can of } \\
\text { Monster ED }\end{array}$ & $\begin{array}{l}\text { Attenuated peak flow-mediated dilatation response (mean } \pm \text { SD): } B L \text { group } 5.9 \% \pm 4.6 \% \\
\text { vs. ED group } 1.9 \% \pm 2.1 \% ; p=0.03 \text {. Thus, acute exposure to an } E D \text { was shown to } \\
\text { impair arterial endothelial function in healthy young adults. }\end{array}$ \\
\hline $\begin{array}{l}\text { Higgins et al. } \\
{[105]}\end{array}$ & 47-year-old healthy Caucasian male. & $\begin{array}{l}\text { 24-oz Monster } \\
\text { energy }\end{array}$ & $\begin{array}{l}\text { Progressive attenuation of peak flow-mediated dilatation response ninety minutes } \\
\text { later, with a peak reduction of about } 4 \% \text { at } 90 \mathrm{~min} \text {. }\end{array}$ \\
\hline $\begin{array}{l}\text { Higgins et al. } \\
{[119]}\end{array}$ & $\begin{array}{l}44 \text { healthy medical students ( } 34 \text { males, } \\
\text { average age } 24.7 \text { years, average BMI } \\
\left.23.4 \mathrm{~kg} / \mathrm{m}^{2}\right) \text {. }\end{array}$ & $\begin{array}{l}\text { 24-oz can of } \\
\text { Monster ED }\end{array}$ & $\begin{array}{l}\text { Attenuated peak flow-mediated dilatation response (mean } \pm S D) \text { : } B L \text { group } 5.1 \% \pm 4.1 \% \\
\text { vs. ED group } 2.8 \% \pm 3.8 \% ; p=0.004 \text {. Thus, acute exposure to an } E D \text { was shown to } \\
\text { impair arterial endothelial function in healthy young adults. }\end{array}$ \\
\hline
\end{tabular}

\section{Possible Mechanisms Sudden Cardiac Death associated with Energy Drink Consumption}

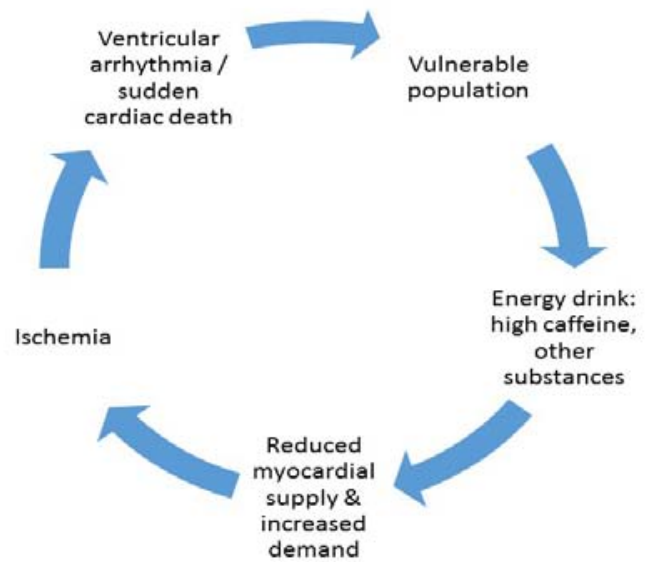

Figure 1: Possible mechanisms sudden cardiac death associated with energy drink consumption.

Table 14: Recommendations regarding Energy Drinks (EDs).

EDs should not be consumed by children, adolescents, or pregnant women.

EDs should not be used for hydration by children and adolescents, and information about the absence of benefit and potential adverse effects should be provided to their caregivers.

EDs should not be available in K-12 schools for sale, nor be advertised to children who attend such schools.

EDs may contain high levels of carbohydrates and calories, which can contribute to obesity.

EDs should not be marketed to nor consumed by vulnerable populations, including those younger than 18 years old, pregnant or breastfeeding women, caffeine naive or sensitive individuals, taking stimulant or caffeine-based medications, or those with certain cardiovascular or medical conditions, or taking medications known to interact with caffeine.

EDs should be avoided before, during, or after strenuous activities, until such time that proper safety and efficacy data are available.

EDs should avoided in patients with cardiovascular risk factors and cardiovascular conditions.

EDs should not be consumed close to bedtime.

ED manufacturers should not promote excessive or rapid consumption of their energy drink, as this 'binge' pattern has been associated with increased adverse events.

Education about EDs and their potential adverse events should be encouraged, especially in schools and universities.

More research on the acute and chronic effects of EDs is needed to clarify who can safely consume them and what is a safe dose to consume.

[83]. In particular, taurine, a nonessential amino acid found in high concentrations in the brain, can interfere with cardiovascular regulation [40,84-87]. Such alterations can lead to Postural Orthostatic Tachycardia Syndrome (POTS).

Once such case involved a 16-year-old female professional volleyball player who gave a 3-month history of orthostatic intolerance and episodes of transient loss of consciousness [83]. She reported that one week prior to the onset of her orthostatic symptoms, she started drinking 4-5 cans of Red Bull ED a day. Her neurological and cardiovascular workup, combined with a positive tilt table test, was suggestive of POTS, a type of orthostatic incompetence [88]. Her clinical symptoms resolved within one week of discontinuation of ED consumption and confirmatory tests performed one month later were reportedly normal.

Recap: Postural orthostatic tachycardia syndrome can be rarely seen in normal healthy athletes following chronic consumption of 4-5 
cans/day of EDs.

\section{Sudden cardiac death}

Case reports exist describing sudden cardiac death triggered by ED use in conjunction with exercise (Table 12) [10]. There is biological plausibility for sudden death, given that caffeine use during exercise reduces coronary artery flow reserve and increases myocardial oxygen demand [8]. These physiologic phenomena can be exacerbated by ED use because of the increased myocardial oxygen demand and reduced coronary flow that may follow their acute consumption $[7,8,66,89,90]$. Thus, a proposed mechanism for sudden cardiac death associated with ED consumption is shown in Figure 1.

The FDA's Center for Food Safety and Applied Nutrition Adverse Event Reporting System Voluntary and Mandatory Reports on 5h Energy, Red Bull' ED, Monster Energy, and Rockstar (Rockstar Inc., Las Vegas, NV, USA) ED in 2012 reported 18 deaths in individuals related to consumption of these energy products [91]. In many cases, confounding variables in addition to $\mathrm{ED}$ consumption are present [92-94]. These include co-ingestions (e.g., drugs), genetic predispositions, and strenuous exercise. Accordingly, because specific causality cannot be attributed to ED consumption alone, atrisk individuals should avoid ED consumption [1,95-97].

Recap: Sudden cardiac death is associated with consumption of EDs in normal young healthy persons or in those with underlying heart disease.

\section{Endothelial dysfunction}

Endothelial cells form the inner lining of blood vessels and have basal and inducible metabolic/synthetic functions, which allow them to carry out multiple important tasks in the vasculature and muscles $[98,99]$. Normal endothelial function is promoted by exercise and a healthy diet $[99,100]$.

The high levels of caffeine and caffeine-like substances in ED may adversely affect endothelial function, thus being associated with vasoconstriction, poor vascular reactivity, coronary artery disease, cerebrovascular disease, and peripheral arterial disease (Table 13) $[7,8,101]$.

In the short term, endothelial dysfunction manifesting as an impaired ability to dilate the coronary arteries may reduce coronary blood flow and oxygen delivery [102,103]. Following exposure to various environmental stressors, the impaired ability to dilate the coronary arteries could result in supply-demand imbalance or coronary spasm, potentially leading to myocardial ischemia and/or cardiac arrhythmias such as ventricular tachycardia/fibrillation [104].

Recap: Reduced endothelial function is associated with consumption of EDs in normal young healthy persons.

\section{Possible Chronic Effects}

Despite little research in the long-term effects of EDs, chronic effects are plausible. For example, chronic daily elevations of blood pressure over many years may lead to hypertensive changes in the heart and development of atherosclerosis, and an increased risk of acute coronary syndrome and stroke [106]. Chronic endothelial dysfunction from long-term ED consumption may predispose users to coronary artery disease, cerebrovascular disease, and peripheral arterial disease. At least one case of accelerated atherosclerosis case was described in a 26-year-old Hispanic male with chronic and excessive consumption of EDs [76]. Given to the dearth of information on the topic, further research is needed establish the safety of long-term ED consumption.

Recap: Chronic exposure to EDs may increase cardiovascular risk factors and translate into an increased incidence of premature cardiovascular disease.

\section{Recommendations}

It is clear that ED consumption is associated with adverse cardiovascular events including death in both youth and adults $[10,30,91]$. However, the majority of ED-related cardiovascular events, however, occur in patients without any underlying cardiac condition [95]. A recent review of the published cases of adverse cardiac events after ED ingestion noted that 15 of the 17 cases (88.2\%) occurred in persons $<30$ years of age and that cardiac investigations did not reveal any predisposing cardiac abnormality in the majority of cases [107].

Underreporting of adverse effects of EDs is a widespread problem given that EDs are not usually screened for despite ED prevalence $[10,12]$. In a 2012 FDA report, 18 deaths and one nonfatal myocardial infarction were associated with consumption of EDs [91]. With a true event capture rate, it can be inferred that 180 or more actual deaths related to ED consumption occurred [108]. Considering the difficulty of determining true event rates, physician inquiries and public campaigns regarding the importance of limiting ED use are necessary $[10,63]$.

The public should be aware of the potential hazards of EDs [5]. Their purported "benefits" have not been supported by rigorous scientific evidence [12,109-112]. Especially concerning is the observed association between ED consumption, poor mental health, and substance abuse behavior (cigarette, marijuana, alcohol, and illicit drug use) [113,114-119].

In 2007, the American Institute of Medicine recommended prohibition of ED use for children and adolescents [115,120]. In 2013, this group further recommended that while caffeine is among the most heavily studied food ingredients, there still remains many unanswered questions with respect to adolescent population [116,121-123].

To date, for healthy adults FDA has cited $400 \mathrm{mg}$ a day as a safe consumption limit; however, they have not set a level of safe consumption of caffeine for younger people. In 2013, the International Sport Society stated that EDs contain many ingredients who safety is unknown. They therefore recommended that children and adolescents should not consume EDs without parental permission [117,124,125].

In 2013, Health Canada stipulated that the daily caffeine intake for younger children should not be greater than $2.5 \mathrm{mg} / \mathrm{kg}$ of body weight [118]. Thus, EDs are not recommended.

Re-labeling EDs to "foods and drinks" would subject these products to more FDA scrutiny. Ideally, this would lead to the eventual limitation of the caffeine content in EDs, restriction of sales to young persons, and clear labelling of contents with appropriate warnings for at-risk populations [126-128]. 
Based on our review, our suggestions regarding ED consumption are summarized in Table 14.

\section{Conclusions}

Monster Energy Drink operates under a campaign slogan of "Unleash the Beast". But at what cost? Indeed, by "unleashing" the new "beast" of EDs and/or excess consumption leading to high levels of caffeine, we have now seen significant adverse events, especially in susceptible patients. With respect to the cardiovascular system, consumption of EDs is associated with increased demand of the heart via increased sympathetic tone, blood pressure, inotropy, and arrhythmias. There also may be concurrently reduced coronary artery blood supply via endothelial dysfunction, platelet aggregation, coronary thrombosis, and coronary spasm. Acutely, these changes are associated with complications in healthy persons and cardiac patients. While the acute cardiovascular consequences of consuming EDs have been described, chronic cardiovascular consequences are not well studied and more research is needed. For now, those vulnerable to their effects should avoid them, and others should wait until more research is available to determine the safety and efficacy of EDs.

\section{Author Contributions}

Authors contributed equally to effort and content of the manuscript.

\section{References}

1. Higgins JP, Tuttle TD, Higgins CL. Energy beverages: Content and safety. Mayo Clin. Proc. 2010; 85: 1033-1041.

2. Seifert SM, Schaechter JL, Hershorin ER, Lipshultz SE. Health effects of energy drinks on children, adolescents, and young adults. Pediatrics. 2011 127: $511-528$

3. Quinlivan A, Irwin C, Grant GD, Anoopkumar-Dukie S, Skinner T, Leveritt $\mathrm{M}$, et al. The Effects of Red Bull ${ }^{\circledR}$ Energy Drink Compared with Caffeine on Cycling Time Trial Performance. Int. J. Sports Physiol. Perform. 2015; 10: 897-901.

4. Howard MA, Marczinski CA. Acute effects of a glucose energy drink on behavioral control. Exp. Clin. Psychopharmacol. 2010; 18: 553-561.

5. Kumar G, Park S, Onufrak S. Perceptions about energy drinks are associated with energy drink intake among U.S. youth. Am. J. Health Promot. 2015; 29 238-244.

6. Anonymous. Energy drinks fuel the obesity epidemic. Br. Dent. J. 2015; 218: 345.

7. Higgins JP, Ortiz BL. Energy drink ingredients and their effect on endothelial function: A Review. Int. J. Clin. Cardiolol. 2014; 1: 1-6.

8. Higgins JP, Babu KM. Caffeine reduces myocardial blood flow during exercise. Am. J. Med. 2013; 126: 730.e1-730.e8.

9. Center for Science in the Public Interest. Caffeine Content of Food \& Drugs. 2014.

10. Goldfarb M, Tellier C, Thanassoulis G. Review of published cases of adverse cardiovascular events after ingestion of energy drinks. Am. J. Cardiol. 2014; 113: $168-172$

11. Heckman MA, Weil J, Gonzalez de Mejia E. Caffeine (1,3,7-trimethylxanthine) in foods: A comprehensive review on consumption, functionality, safety, and regulatory matters. J. Food Sci. 2010; 75: R77-R87.

12. Ibrahim NK, Iftikhar R. Energy drinks: Getting wings but at what health cost? Pak. J. Med. Sci. 2014; 30: 1415-1419.

13. ACOG. Committee Opinion No. 462: Moderate caffeine consumption during pregnancy. Obstet. Gynecol. 2010; 116: 467-468.
14. Chen L, Bell EM, Browne ML, Druschel CM, Romitti PA. Exploring maternal patterns of dietary caffeine consumption before conception and during pregnancy. Matern. Child Health J. 2014; 18: 2446-2455.

15. Sanchis-Gomar F, Pareja-Galeano H, Cervellin G, Lippi G, Earnest CP. Energy Drink Overconsumption in Adolescents: Implications for Arrhythmias and Other Cardiovascular Events. Can. J. Cardiol. 2015; 31: 572-575.

16. Emond JA, Sargent JD, Gilbert-Diamond D. Patterns of Energy Drink Advertising over US Television Networks. J. Nutr. Educ. Behav. 2015; 47: 120-126.e1.

17. Larson N, Laska MN, Story M, Neumark-Sztainer D. Sports and energy drink consumption are linked to health-risk behaviours among young adults. Public Health Nutr. 2015; 18: 2794-2803.

18. Kim IK, Kim KM. Energy drink consumption patterns and associated factors among nursing students: A descriptive survey study. J. Addict. Nurs. 2015; 26: 24-31.

19. Miyake ER, Marmorstein NR. Energy drink consumption and later alcohol use among early adolescents. Addict. Behav. 2015; 43: 60-65.

20. Poulos NS, Pasch KE. Energy drink consumption is associated with unhealthy dietary behaviors among college youth. Perspect. Public Health.2015; 135: 316-321.

21. Verster JC, Benjaminsen JM, van Lanen JH, van Stavel NM, Olivier B. Effects of mixing alcohol with energy drink on objective and subjective intoxication: Results from a Dutch on-premise study. Psychopharmacology. 2015; 232: 835.842.

22. Bonar EE, Cunningham RM, Polshkova S, Chermack ST, Blow FC, Walton MA. Alcohol and energy drink use among adolescents seeking emergency department care. Addict. Behav. 2015; 43: 11-17.

23. Trapp GS, Allen KL, O'Sullivan T, Robinson M, Jacoby P, Oddy WH. Energy drink consumption among young Australian adults: Associations with alcohol and illicit drug use. Drug Alcohol Depend. 2014; 134: 30-37.

24. McKetin R, Coen A, Kaye S. A comprehensive review of the effects of mixing caffeinated energy drinks with alcohol. Drug Alcohol Depend. 2015; 151: 15-30.

25. Striley CW, Khan SR. Review of the energy drink literature from 2013 Findings continue to support most risk from mixing with alcohol. Curr. Opin. Psychiatry. 2014; 27: 263-238.

26. Spierer DK, Blanding N, Santella A. Energy drink consumption and associated health behaviors among university students in an urban setting. J. Community Health. 2014; 39: 132-138.

27. George J, Murphy T, Roberts R, Cooksley WG, Halliday JW, Powell LW. Influence of alcohol and caffeine consumption on caffeine elimination. Clin. Exp. Pharmacol. Physiol. 1986; 13: 731-736.

28. Cotter BV, Jackson DA, Merchant RC, Babu KM, Baird JR, Nirenberg T, et al. Energy drink and other substance use among adolescent and young adult emergency department patients. Pediatr. Emerg. Care 2013; 29: 1091-1097.

29. Gunja N, Brown JA. Energy drinks: Health risks and toxicity. Med. J. Aust. 2012; 196: 46-49.

30. Seifert SM, Seifert SA, Schaechter JL, Bronstein AC, Benson BE, Hershorin $\mathrm{ER}$, et al. An analysis of energy-drink toxicity in the National Poison Data System. Clin. Toxicol. (Phila.). 2013; 51: 566-574.

31. Newton BD, Okuda DT. Pontine myelinolysis following excessive consumption of commercial energy drinks. Neurol. Neuroimmunol. Neuroinflammation. 2015; 2: e91.

32. Calabro RS, Italiano D, Gervasi G, Bramanti P. Single tonic-clonic seizure after energy drink abuse. Epilepsy Behav. 2012; 23: 384-385.

33. Nordt SP, Vilke GM, Clark RF, Lee Cantrell F, Chan TC, Galinato M, et al. Energy drink use and adverse effects among emergency department patients. J. Community Health. 2012; 37: 976-981.

34. Trabulo D, Marques S, Pedroso E. Caffeinated energy drink intoxication. BMJ Case Rep. 2011; 2011: e3322. 
35. Grasser EK, Yepuri G, Dulloo AG, Montani JP. Cardio- and cerebrovascular responses to the energy drink Red Bull in young adults: A randomized cross over study. Eur. J. Nutr. 2014; 53: 1561-1571.

36. Elitok A, Oz F, Panc C, Sarikaya R, Sezikli S, Pala Y, et al. Acute effects of Red Bull energy drink on ventricular repolarization in healthy young volunteers: A prospective study. Anatol. J. Cardiol. 2015; 15: 919-922.

37. Robertson D, Frolich JC, Carr RK, Watson JT, Hollifield JW, Shand DG, et al. Effects of caffeine on plasma renin activity, catecholamines and blood pressure. N. Engl. J. Med. 1978; 298: 181-186.

38. Papaioannou TG, Vlachopoulos C, loakeimidis $\mathrm{N}$, Alexopoulos $\mathrm{N}$ Stefanadis $C$. Nonlinear dynamics of blood pressure variability after caffeine consumption. Clin. Med. Res. 2006; 4: 114-118.

39. Cohen DL, Townsend RR. Does consumption of high-caffeine energy drinks affect blood pressure? J. Clin. Hypertens. (Greenwich). 2006; 8: 744-745.

40. Baum $M$, Weiss $M$. The influence of a taurine containing drink on cardiac parameters before and after exercise measured by echocardiography. Amino Acids. 2001; 20: 75-82

41. Steinke L, Lanfear DE, Dhanapal V, Kalus JS. Effect of "energy drink" consumption on hemodynamic and electrocardiographic parameters in healthy young adults. Ann. Pharmacother. 2009; 43: 596-602.

42. Franks AM, Schmidt JM, McCain KR, Fraer M. Comparison of the effects of energy drink vs. caffeine supplementation on indices of 24-h ambulatory blood pressure. Ann. Pharmacother. 2012; 46: 192-199.

43. Peveler WW, Sanders GJ, Marczinski CA, Holmer B. Effects of Energy Drinks on Economy and Cardiovascular Measures. Journal of strength and conditioning research. 2017; 31: 882-887.

44. Kozik T, Shah S, Bhattacharyya M, Franklin T, Connolly T, Chien W, et al Cardiovascular responses to energy drinks in a healthy population: The C-energy study. The American Journal of Emergency Medicine. 2016; 34 1205-1209.

45. Basrai M, Schweinlin A, Menzel J, Mielke H, Weikert C, Dusemund B, et al. Energy Drinks Induce Acute Cardiovascular and Metabolic Changes Pointing to Potential Risks for Young Adults: A Randomized Controlled Trial. The Journal of Nutrition. 2019; 149: 441-450.

46. Nowak D, Gośliński M, Wesołowska A, Berenda K, Popławski C. Effects of Acute Consumption of Noni and Chokeberry Juices vs. Energy Drinks on Blood Pressure, Heart Rate, and Blood Glucose in Young Adults. Evidencebased complementary and alternative medicine: eCAM. 2019; e6076751.

47. Brothers RM, Christmas KM, Patik JC, Bhella PS. Heart rate, blood pressure and repolarization effects of an energy drink as compared to coffee. Clin Physiol Funct Imaging. 2017; 37: 675-681.

48. Gray B, Ingles J, Medi C, Driscoll T, Semsarian C. Cardiovascular Effects of Energy Drinks in Familial Long QT Syndrome: A Randomized Cross-Over Study, International Journal of Cardiology. 2017; 231: 150-154.

49. Shah S, Dargush A, Potts V, Lee M, Millard-Hasting BM, Williams B, et al. Effects of Single and Multiple Energy Shots on Blood Pressure and Electrocardiographic Parameters. The American Journal of Cardiology. 2016; 117: 465-468.

50. Usman A, Jawaid A. Hypertension in a young boy: An energy drink effect. BMC Res. Notes. 2012; 5: 591.

51. Satoh $\mathrm{H}$. Elecropharmacology of taurine on the hyperpolarization-activated inward current and the sustained inward current in spontaneously beating rat sino-atrial nodal cells. J. Pharmacol. Sci. 2003; 91: 229-938.

52. Rottlaender D, Motloch LJ, Reda S, Larbig R, Hoppe UC. Cardiac arrest due to long QT syndrome associated with excessive consumption of energy drinks. Int. J. Cardiol. 2012; 158: e51-e52.

53. Dufendach KA, Horner JM, Cannon BC, Ackerman MJ. Congenital type 1 long QT syndrome unmasked by a highly caffeinated energy drink. Heart Rhythm: Off. J. Heart Rhythm Soc. 2012; 9: 285-288.

54. Guidance for Industry: E14: Clinical Evaluation of QT/QTc Interval Prolongation and Proarrhythmic Potential for Non-antiarrhythmic Drugs.
2005.

55. Artin B, Singh M, Richeh C, Jawad E, Arora R, Khosla S. Caffeine-related atrial fibrillation. Am. J. Ther. 2010; 17: e169-e171.

56. Turagam MK, Velagapudi P, Kocheril AG, Alpert MA. Commonly Consumed Beverages in Daily Life: Do They Cause Atrial Fibrillation? Clin. Cardiol. 2015; 38: 317-322.

57. Di Rocco JR, During A, Morelli PJ, Heyden M, Biancaniello TA. Atrial fibrillation in healthy adolescents after highly caffeinated beverage consumption: Two case reports. J. Med. Case Rep. 2011; 5: 18.

58. Izquierdo Fos I, Vazquez Gomis RM, Vazquez Gomis C, Piernas R, Climent Forner E, Llaguno Salvador MD, et al. Atrial fibrillation after ingestion of a high energy drink. An. Pediatr. (Barc.). 2012; 77: 417-419.

59. Nagajothi N, Khraisat A, Velazquez-Cecena JL, Arora R, Raghunathan K, Patel R, et al. Energy drink-related supraventricular tachycardia. Am. J. Med. 2008; 121: e3-e4.

60. Kaoukis A, Panagopoulou V, Mojibian HR, Jacoby D. Reverse Takotsubo cardiomyopathy associated with the consumption of an energy drink. Circulation. 2012; 125: 1584-1585.

61. Peake ST, Mehta PA, Dubrey SW. Atrial fibrillation-related cardiomyopathy: A case report. J. Med. Case Rep. 2007; 1: 111.

62. Mattioli AV, Pennella S, Farinetti A, Manenti A. Energy Drinks and atrial fibrillation in young adults. Clinical Nutrition. 2018; 37: 1073-1074.

63. Ward AE, Lipshultz SE, Fisher SD. Energy drink-induced near-fatal ventricular arrhythmia prevented by an intracardiac defibrillator decades after operative "repair" of tetralogy of Fallot. Am. J. Cardiol. 2014; 114: 1124 1125

64. Avci S, Sarikaya R, Buyukcam F. Death of a young man after overuse of energy drink. Am. J. Emerg. Med. 2013; 31: 1624.e3-1624.e4.

65. Cannon ME, Cooke CT, McCarthy JS. Caffeine-induced cardiac arrhythmia: An unrecognised danger of healthfood products. Med. J. Aust. 2001; 174: 520-521.

66. Berger AJ, Alford K. Cardiac arrest in a young man following excess consumption of caffeinated "energy drinks". Med. J. Aust. 2009; 190: 41-43.

67. Rutledge M, Witthed A, Khouzam RN. It took a RedBull to unmask Brugada syndrome. Int. J. Cardiol. 2012; 161: e14-e15.

68. Goldfarb M, Tellier C, Thanassoulis G. Review of published cases of adverse cardiovascular. American Journal of Cardiology. 2014; 113: 168-172.

69. Israelit S, Strizevsky A, Raviv B. ST elevation myocardial infarction in a young patientafter ingestion of caffeinated energy drink and ecstasy. World J. Emerg. Med. 2012; 3: 305-307.

70. Scott MJ, El-Hassan M, Khan AA. Myocardial infarction in a young adult following the consumption of a caffeinated energy drink. BMJ Case Rep. 2011; 2011: 3854

71. Holmgren P, Norden-Pettersson L, Ahlner J. Caffeine fatalities-Four case reports. Forensic Sci. Int. 2004; 139: 71-73.

72. Doerner JM, Kuetting DL, Luetkens JA, Naehle CP, Dabir D, Homsi R, et al. Caffeine and taurine containing energy drink increases left ventricular contractility in healthy volunteers. Int. J. Cardiovasc. Imaging. 2015; 31: 595601.

73. Wilson RE, Kado HS, Samson R, Miller AB. A case of caffeine-induced coronary artery vasospasm of a 17-year-old male. Cardiovasc. Toxicol. 2012; 12: 175-179.

74. Benjo AM, Pineda AM, Nascimento FO, Zamora C, Lamas GA, Escolar E. Left main coronary artery acute thrombosis related to energy drink intake. Circulation 2012; 125: 1447-1448.

75. Ünal S, Şensoy B, Yilmaz S, Gamze Ünal G, Süleymanoğlu M, Şen F, et al. Left main coronary artery thrombosis and acute anterior myocardial infarction related to energy drink. International Journal of Cardiology. 2015; 179: 66-67. 
76. Solomin D, Borron SW, Watts SH. STEMI Associated with Overuse of Energy Drinks. Case Rep. Emerg. Med. 2015; 2015: 537689.

77. Zacher J, May E, Horlitz M. Binge drinking alcohol with caffeinated "energy drinks", prolonged emesis and spontaneous coronary artery dissection: a case report, review of the literature and postulation of a pathomechanism. Clin Res Cardiol. 2018; 107: 975-979.

78. Wajih Ullah M, Lakhani S, Siddiq W, Handa A, Kahlon Y, Siddiqui T. Energy Drinks and Myocardial Infarction. Cureus. 2018; 10: e2658.

79. Reissig CJ, Strain EC, Griffiths RR. Caffeinated energy drinks-A growing problem. Drug Alcohol Depend. 2009; 99: 1-10.

80. Silverio A, Prota C, di Maio M, Polito MV, Cogliani FM, Citro R, et al. Aortic dissection in patients with autosomal dominant polycystic kidney disease: A series of two cases and a review of the Literature. Nephrology (Carlton). 2015; 20: 229-235.

81. Jonjev ZS, Bala G. High-energy drinks may provoke aortic dissection. Coll. Antropol. 2013; 37: 227-229.

82. Humphrey JD, Schwartz MA, Tellides G, Milewicz DM. Role of Mechanotransduction in Vascular Biology: Focus on Thoracic Aortic Aneurysms and Dissections. Circ. Res. 2015; 116: 1448-1161.

83. Terlizzi R, Rocchi C, Serra M, Solieri L, Cortelli P. Reversible postura tachycardia syndrome due to inadvertent overuse of Red Bull. Clin. Auton. Res. 2008; 18: 221-223.

84. Huxtable RJ. Physiological actions of taurine. Physiol. Rev. 1992; 72: 101 163.

85. Yang CP, Lin MT. Amino acids injected into the cerebroventricular system induce an enhancement of reflex bradycardia in the rat. Neuropharmacology. 1983; 22: 919-922.

86. Alford $\mathrm{C}, \mathrm{Cox} \mathrm{H}$, Wescott R. The effects of red bull energy drink on human performance and mood. Amino Acids. 2001; 21: 139-150.

87. Bichler A, Swenson A, Harris MA. A combination of caffeine and taurine has no effect on short term memory but induces changes in heart rate and mean arterial blood pressure. Amino Acids. 2006; 31: 471-476

88. NINDS. Postural Tachycardia Syndrome Information Page. 2015.

89. Higgins JP, Yang B, Ortiz B, Herrin N, Doolittle J, Kahlden K, et al Consumption Of Energy Beverage Is Associated With An Attenuation O Arterial Endothelial Flow-mediated Dilatation. Arterioscler. Thromb. Vasc. Biol. 2014; 34: A519.

90. Worthley MI, Prabhu A, de Sciscio P, Schultz C, Sanders P, Willoughby SR Detrimental effects of energy drink consumption on platelet and endothelia function. Am. J. Med. 2010; 123: 184-187.

91. CFSAN Adverse Event Reporting System. Voluntary and Mandatory Reports on 5-Hour Energy, Monster Energy, and Rockstar Energy Drink. 2015.

92. Teen Girl Dies of 'Caffeine Toxicity' after Downing 2 Energy Drinks. 2015

93. Red Bull, Alcohol and Drugs 'Can Spark Violence'. 2014

94. Jackson C. Teenage Girl Is Dead after Consuming Red Bull Energy Drink 2014.

95. Ernest D, Chia M, Corallo CE. Profound hypokalaemia due to Nurofen Plus and Red Bull misuse. Crit. Care Resusc. J. Australas. Acad. Crit. Care Med. 2010; 12: 109-110.

96. Higgins JP, Ananaba IE, Higgins CL. Sudden cardiac death in young athletes: Preparticipation screening for underlying cardiovascular abnormalities and approaches to prevention. Phys. Sportsmed. 2013; 41: 81-93.

97. Wolk BJ, Ganetsky M, Babu KM. Toxicity of energy drinks. Curr. Opin. Pediatr. 2012; 24: 243-251.

98. Deanfield JE, Halcox JP, Rabelink TJ. Endothelial function and dysfunction Testing and clinical relevance. Circulation. 2007; 115: 1285-1295.

99. Blanch N, Clifton PM, Keogh JB. A systematic review of vascular and endothelial function: Effects of fruit, vegetable and potassium intake. Nutr.
Metab. Cardiovasc. Dis.: NMCD. 2015; 25: 253-266.

100. Ashor AW, Lara J, Siervo M, Celis-Morales C, Oggioni C, Jakovljevic DG et al. Exercise modalities and endothelial function: A systematic review and dose-response meta-analysis of randomized controlled trials. Sports Med. 2015; 45: 279-296.

101. Veerasamy M, Bagnall A, Neely D, Allen J, Sinclair H, Kunadian V. Endothelial dysfunction and coronary artery disease: A state of the art review. Cardiol. Rev. 2015; 23: 119-129.

102. Suwaidi JA, Hamasaki S, Higano ST, Nishimura RA, Holmes DR Jr, Lerman A. Long-term follow-up of patients with mild coronary artery disease and endothelial dysfunction. Circulation. 2000; 101: 948-954.

103. Jones CJ, Kuo L, Davis MJ, DeFily DV, Chilian WM. Role of nitric oxide in the coronary microvascular responses to adenosine and increased metabolic demand. Circulation. 1995; 91: 1807-1813.

104.Looi KL, Grace A, Agarwal S. Coronary artery spasm and ventricular arrhythmias. Postgrad. Med. J. 2012; 88: 465-471.

105. Higgins JP. Endothelial function acutely worse after drinking energy beverage. Int. J. Cardiol. 2013; 168: e47-e49.

106. Tabas I, Garcia-Cardena G, Owens GK. Recent insights into the cellular biology of atherosclerosis. J. Cell Biol. 2015; 209: 13-22.

107. Shah SA, Lacey CS, Bergendahl T, Kolasa M, Riddock IC. QTC interval prolongation with high dose energy drink consumption in a healthy volunteer. Int. J. Cardiol. 2014; 172: e336-e337.

108. Heinrich J. Adverse Drug Events: Substantial Problem but Magnitude Uncertain; United States General Accounting Office: Washington, DC, USA 2000.

109. Goel V, Manjunatha S, Pai KM. Effect of red bull energy drink on auditory reaction time and maximal voluntary contraction. Indian J. Physiol. Pharmacol. 2014; 58: 17-21.

110. Pai KM, Kamath A, Goel V. Effect of Red Bull energy drink on muscle performance: An electromyographic overview. J. Sports Med. Phys. Fitness. 2014; 55: 1459-1465.

111. Eckerson JM, Bull AJ, Baechle TR, Fischer CA, O'Brien DC, Moore GA, et al. Acute ingestion of sugar-free red bull energy drink has no effect on upper body strength and muscular endurance in resistance trained men. J. Strength Cond. Res. 2013; 27: 2248-2254.

112. Nelson MT, Biltz GR, Dengel DR. Cardiovascular and ride time-to-exhaustion effects of an energy drink. J. Int. Soc. Sports Nutr. 2014; 11: 2.

113. Azagba S, Langille D, Asbridge M. An emerging adolescent health risk: Caffeinated energy drink consumption patterns among high school students. Prev. Med. 2014; 62: 54-59.

114. Arria AM, Caldeira KM, Kasperski SJ, O'Grady KE, Vincent KB, Griffiths RR, et al. Increased alcohol consumption, nonmedical prescription drug use, and illicit drug use are associated with energy drink consumption among college students. J. Addict. Med. 2010; 4: 74-80.

115. Sports drinks and energy drinks for children and adolescents: Are they appropriate? Pediatrics. 2011; 127: 1182-1189.

116. MEDICINE IO. Caffeine in Food and Dietary Supplements: Examining Safety-Workshop Summary; The National Academies Press Washington, DC: Washington, DC, USA. 2014.

117. Campbell B, Wilborn C, LaBounty P, Taylor L, Nelson MT, Greenwood M, et al. International Society of Sports Nutrition position stand: Energy drinks. J. Int. Soc. Sports Nutr. 2013; 10: 1.

118. Goldman RD. Caffeinated energy drinks in children. Can. Fam. Phys. Med. Fam. Can. 2013; 59: 947-948.

119. Higgins JP, Liras GN, Liras IN, Jacob R, Husain F, Pabba KC, et al. Energy Drink Effects on Hemodynamics and Endothelial Function in Young Adults. Cardiology. 2021; 146: 258-262.

120. Higgins JP, Babu K, Deuster PA, Shearer J. Energy Drinks: A Contemporary 
Issues Paper. Curr Sports Med Rep. 2018; 17: 65-72.

121. Nadeem IM, Shanmugaraj A, Sakha S, Horner NS, Ayeni OR, Khan M. Energy Drinks and Their Adverse Health Effects: A Systematic Review and Meta-analysis. Sports Health. 2021; 13: 265-277.

122. Tarragon E, Calleja-Conde J, Giné E, Segovia-Rodríguez L, DuránGonzález P, Echeverry-Alzate V. Alcohol mixed with energy drinks: what about taurine? Psychopharmacology (Berl). 2021; 238: 1-8.

123. Moussa M, Hansz K, Rasmussen M, Gillman C, Pollard C, Kwak E, et al. Cardiovascular Effects of Energy Drinks in the Pediatric Population. Pediatr Emerg Care. 2020; 37: 578-582.

124. Piccioni A, Covino M, Zanza C, Longhitano Y, Tullo G, Bonadia N, et al. Energy drinks: a narrative review of their physiological and pathological effects. Intern Med J. 2021; 51: 636-646.
125. Gutiérrez-Hellín J, Varillas-Delgado D. Energy Drinks and Sports Performance, Cardiovascular Risk, and Genetic Associations; Future Prospects. Nutrients. 2021; 13: 715.

126. Guest NS, VanDusseldorp TA, Nelson MT, Grgic J, Schoenfeld BJ, Jenkins NDM, et al. International society of sports nutrition position stand: caffeine and exercise performance. J Int Soc Sports Nutr. 2021; 18: 1.

127. Yasuma N, Imamura K, Watanabe K, Nishi D, Kawakami N, Takano A Association between energy drink consumption and substance use in adolescence: A systematic review of prospective cohort studies. Drug Alcohol Depend. 2021; 219: 108470.

128. Lasheras I, Seral P, Alonso-Ventura V, Santabárbara J. The impact of acute energy drink consumption on electrical heart disease: A systematic review and meta-analysis. J Electrocardiol. 2021; 65: 128-135. 